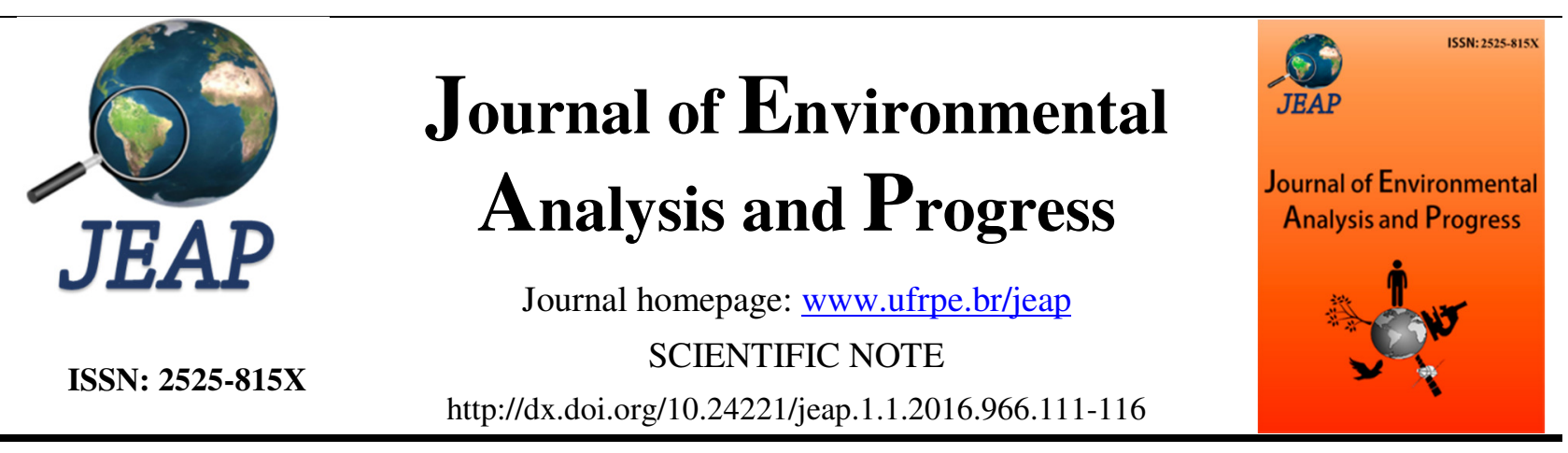

\title{
New records of host plants used by a weaver ants Camponotus textor Forel, 1899 (Hymenoptera: Formicidae)
}

\author{
Jean Carlos Santos ${ }^{1}$, Jonas José Mendes Aguiar², Tatiana Rosa Alves ${ }^{1}$, Wanessa Rejane Almeida ${ }^{3}$, \\ Kleber Del-Claro ${ }^{4}$ \\ a Laboratório de Ecologia Evolução e Biodiversidade-LEEBIO, Instituto de Biologia-InBio, Universidade Federal de \\ Uberlândia-UFU, Av. Pará 1720, CEP: 38405-320. Uberlândia, Minas Gerais, Brasil. E-mail: jcsantos@ ufu.br. \\ b Programa de Pós-Graduação em Entomologia, Faculdade de Filosofia Ciências e Letras de Ribeirão Preto-FFCLRP, \\ Universidade de São Paulo-USP, Av. Bandeirantes, 3900, CEP: 14.040-901, Ribeirão Preto, São Paulo, Brasil. \\ ${ }^{\mathrm{c}}$ Programa de Pós-graduação em Biologia Vegetal, UFU. \\ ${ }^{\mathrm{d}}$ Laboratório de Ecologia Comportamental e de Interações-LECI, InBio, UFU.
}

\begin{abstract}
A R T I C L E I N F O
Received 20 Sep 2016

Accepted 23 Sep 2016

Published 13 Oct 2016

A B S T R A C T

Weaver ants nest on plants, but the extent of such associations is unknown for many species. Literature records of weaver ant host plants from 1945 to 2016 showed that Camponotus textor Forel (= Camponotus senex), the Brazilian savanna weaver ant, was recorded on 17 plant species belonging to 11 families. The field survey recorded nine plant species in eight families at Brazilian Cerrado. Overall, The list was expanded to a total of 24 host plant species and 14 families, including economically important tree species as mango, citrus and jambo trees. This host plants show potential to enhance the establishment of weaver ants, facilitating the role in biocontrol as deterrents of phytophagous insect pests of economically important plants.
\end{abstract}

Keywords: Brazilian savanna, Camponotus senex, host plant, nest, nidification, survey.

\section{Introduction}

In tropical regions, ants are among the most abundant arthropods (Hölldolbler \& Wilson, 1990; Majer et al., 1994). Ants developed several relationships with plant and animal species ranging from facultative to neutral to obligatory (Jolivet, 1996; Bronstein, 1998; Delabie, 2001; Del-Claro \& Torezan-Silingardi, 2012). Specifically, a group of ants, known as weaver ants, are capable of producing the nests with the silk produced by their larvae on host plants (Hölldobler \& Wilson, 1977, 1990). The plants used by these ants are considered host because the use of foliage to build nests. For instance, Oecophylla smaragdina Fabricius typically uses leaves of a certain 'normal' size that are not very waxy (Blüthgen \& Fiedler, 2002) and has been observed some ant benefit to these plant species (Way \& Khoo, 1991).

The ants can utilize many plants in a wide range of habitats (Hölldobler, 1993). Host plants also serve as an arboreal hunting ground provisioned with insects and other arthropods that the ant preys on, support trophobiont species that the ant tends for honeydew and nectar exudates that the ant consumes (Blüthgen et al., 2004). Many host plants used by weaver ants have an economic value which could derive benefit from weaver ant occupancy; the prospective applications for this biological control agent are considerable (e.g., Way \& Khoo, 1991, 1992; Peng et al., 1995; Sporleder \& Rapp, 1998; Van Mele \& Cuc, 2000; Van Mele \& Van Lenteren, 2002; Van Mele, 2008).

Camponotus textor Forel $(=C$. senex $)$ is an arboreal Neotropical weaver ant that inhabits mature rainforest canopy, where it builds their nests using the silk produced by their larvae to attach leaves (Forel, 1899, 1905; Wheeler, 1915; Schremmer, 1979; Holldobler \& Wilson, 1983). The present study brings together all host plant 
species records for C. textor published since 1899 and through surveys of host plant species used by these ants in the Brazilian Savanna. It may serve as a reference to screen for host plant species to which weaver ant protection could be applied (Van Mele, 2008), as well as hint towards possible plant species with which existing perennial cropping systems could be enriched.

\section{Material and Methods}

Checking taxon of weaver ants

It was considered some weaver ants previously classified as Camponotus senex (Smith, 1858) and C. (Myrmobrachys) textor Forel due to a historical confusion about these taxa (see Longino, 2006). According to Longino (2006), C. senex should be disassociated weaver ants, and in this study, all weaver ants previously named $C$. senex were considered as $C$. textor.

\section{Literature survey}

A literature survey was carried out to identify host plants recorded worldwide for $C$. textor. The literature survey was extensively conducted on the "Web of Science" database that included international archives dating back to 1945 (https://www.webofknowledge.com/) and, additionally, in the "Scholar Google." The search terms 'Camponotus textor' and 'Camponotus senex' were used to obtain records for this species, and 'weaver ant' was used to locate articles that considered this species as a weaver one. For the purpose of this survey, 'host plants' were those that the ant was reported to nest. The plant names were checked against other standardized databases using the system proposed by Angiosperm Phylogeny Group (APG III, 2009), R package to query the Brazilian Flora 2020 dataset. The dataset included in the package was kindly made available by the Brazilian Flora 2020, which is a joint effort by hundreds of taxonomists to provide an improved checklist of plants and fungi that occur in Brazil and supplemented with information in Missouri Botanical Garden website (http://www.tropicos.org/NameSearch.aspx/).

\section{Host plant survey}

During the period between 2011 and 2012, 35 ha of forest remnants were surveyed at Parque do Sabiá, Uberlândia, Minas Gerais State, Brazil
(18 $54^{\prime} 52^{\prime \prime} S$ and $\left.48^{\circ} 14^{\prime} 02^{\prime \prime} \mathrm{W}\right)$. Located in the eastern sector of the municipality of Uberlândia, Minas Gerais State, Brazil, the Parque do Sabiá complex comprises an area of $1,850,000 \mathrm{~m}^{2}$ with $350,000 \mathrm{~m}^{2}$ of forest remnants, seven reservoirs, one large and seven smaller lakes. The Parque do Sabiá complex was created with the main purpose of sports practices and to the conservation of remnants fragments of forest. The vegetation consisted of savannah remnants with effects of local anthropic interference (Rosa \& Schiavini, 2006). A plant was considered a host species only when the ant was confirmed nesting on it. Some records of host plants of personal observations also incorporated into this study. Host plants were classified into morphospecies in the field, and later at the species level in the Herbarium of the Universidade Federal de Uberlândia (UFU). The classification of species of host plants also followed the system proposed by APG III and scientific host plant names were checked in Missouri Botanical Garden website.

\section{Results}

The "Web of Science" and "Scholar Google" database search for 'Camponotus textor' and 'Camponotus senex' returned 539 and 298 records, respectively. The literature survey and the data from this study showed that $C$. textor may host on 17 plant species in 11 families while $C$. senex was recorded in nine plant species in seven families including economically important plant species (see Table 1). The field results showed that $C$. textor uses more frequently individuals of Mangifera. indica $(\mathrm{n}=21)(80 \%)$ (Figure 1). Other plant species were less frequent: Pachira aquatica Aubl. (Malvaceae) $(\mathrm{n}=2)(8 \%)$; Syzygium jambos (L.) Alston (Myrtaceae) $(\mathrm{n}=1)$ (4\%); Pinus elliottii L. (Pinaceae) $(\mathrm{n}=1)(4 \%)$ and Inga laurina $(\mathrm{Sw}$. Willd. (Mimosaceae) $(\mathrm{n}=1)$ (4\%) (Table 1, Fig. 1). Finally, personal observations have reported the occurrence of $C$. textor the following plants: native species as Guazuma ulmifolia Lam. (Malvaceae) and Poincianella pluviosa var. peltophoroides (Benth.) L.P. Queiroz (Fabaceae); and naturalized species like lemon Citrus $x$ limon (L.) Osbeck (Rutaceae), and guava Psidium guajava L. (Myrtaceae). Overall (literature and field survey), we recorded a total of 24 host species and 14 families of plants that host $C$. textor.

Table 1. Records of Camponotus (Myrmobrachys) textor host plants from a survey of the literature (19452016) and in the field.

\begin{tabular}{llllll}
\hline Host plant species & Host plant family & Life form & Establishment & $\begin{array}{l}\text { Considered ants } \\
\text { species }\end{array}$ & References \\
\hline Ceiba pentandra (L.) Gaertn. & Malvaceae & Tree & Native & $\begin{array}{l}\text { Camponotus senex } \\
\text { (Smith) }\end{array}$ & Yanoviak \& Kaspari (2000) \\
Chrysobalanus icaco L. & Chrysobalanaceae & Tree/Shrub & Native & $\begin{array}{l}\text { Camponotus textor } \\
\text { (Forel) }\end{array}$ & Pérez-Lachaud et al (2013)
\end{tabular}


Journal of Environmental Analysis and Progress V. 01 N. 01 (2016) 111-116

\begin{tabular}{|c|c|c|c|c|c|}
\hline Citrus reticulata Blanco & Rutaceae & Tree & Naturalized & $\begin{array}{l}\text { Camponotus sp. aff. } \\
\text { textor/Camponotus } \\
\text { textor (Forel) }\end{array}$ & $\begin{array}{l}\text { Pérez-Lachaud \& Lachaud } \\
\text { (2014)/ Hansson et al. (2011) }\end{array}$ \\
\hline Citrus x limon (L.) Osbeck & Rutaceae & Tree & Naturalized & $\begin{array}{l}\text { Camponotus textor } \\
\text { (Forel) }\end{array}$ & This paper \\
\hline Coffea arabica $\mathrm{L}$. & Rubiaceae & Shrub & Cultivated & $\begin{array}{l}\text { Camponotus senex } \\
\text { (Smith) } \\
\text { Camponotus textor } \\
\text { (Forel) }\end{array}$ & $\begin{array}{l}\text { Schremmer 1979ab, Philpott } \\
\text { 2005/ Philpott et al. (2008) }\end{array}$ \\
\hline $\begin{array}{l}\text { Conostegia xalapensis (Bonpl.) } \\
\text { D. Don ex DC. }\end{array}$ & Melastomataceae & Tree & - & $\begin{array}{l}\text { Camponotus textor } \\
\text { (Forel) }\end{array}$ & Gonthier (2012) \\
\hline Dipteryx oleifera Benth. & Fabaceae & Tree & - & $\begin{array}{l}\text { Camponotus senex } \\
\text { (Smith) }\end{array}$ & Yanoviak \& Kaspari (2000) \\
\hline Faramea hyacinthine Mart & Rubiaceae & Tree/Shrub & Native & $\begin{array}{l}\text { Camponotus senex } \\
\text { (Smith) }\end{array}$ & Santos \& Del-Claro (2009) \\
\hline Guazuma ulmifolia Lam. & Malvaceae & Tree & Native & $\begin{array}{l}\text { Camponotus textor } \\
\text { (Forel) }\end{array}$ & This paper \\
\hline Inga laurina (Sw.) Willd. & Mimosaceae & Tree & Native & $\begin{array}{l}\text { Camponotus textor } \\
\text { (Forel) }\end{array}$ & This paper \\
\hline Inga sp. 1 Mill* & Fabaceae & Tree & Native & $\begin{array}{l}\text { Camponotus textor } \\
\text { (Forel) }\end{array}$ & Longino (2006) \\
\hline Inga sp. 2 Mill* & Fabaceae & Tree & Native & $\begin{array}{l}\text { Camponotus sp. aff. } \\
\text { textor }\end{array}$ & $\begin{array}{l}\text { Pérez-Lachaud \& Lachaud } \\
\text { (2014) }\end{array}$ \\
\hline $\begin{array}{l}\text { Licania apetala (E.Mey.) Fritsch } \\
\text { var. apetala }\end{array}$ & Chrysobalanaceae & Tree & Native & $\begin{array}{l}\text { Camponotus senex } \\
\text { (Smith) }\end{array}$ & Santos \& Del-Claro (2009) \\
\hline Mangifera indica $\mathrm{L}$. & Anacardiaceae & Tree & Cultivated & $\begin{array}{l}\text { Camponotus senex } \\
\text { (Smith) }\end{array}$ & $\begin{array}{l}\text { Santos \& Del-Claro } \\
(2009) / \text { This paper }\end{array}$ \\
\hline Pachira aquatica Aubl. & Melastomataceae & Tree & Native & $\begin{array}{l}\text { Camponotus textor } \\
\text { (Forel) }\end{array}$ & This paper \\
\hline Pinus elliottii $\mathrm{L}$. & Pinaceae & Tree & Naturalized & $\begin{array}{l}\text { Camponotus textor } \\
\text { (Forel) }\end{array}$ & This paper \\
\hline $\begin{array}{l}\text { Poincianella pluviosa var. } \\
\text { peltophoroides (Benth.) L.P. } \\
\text { Queiroz }\end{array}$ & Fabaceae & Tree & Native & $\begin{array}{l}\text { Camponotus textor } \\
\text { (Forel) }\end{array}$ & This paper \\
\hline $\begin{array}{l}\text { Pseudobombax septenatum } \\
\text { (Jacq.) Dugand }\end{array}$ & Melastomataceae & Tree & Native & $\begin{array}{l}\text { Camponotus senex } \\
\text { (Smith) }\end{array}$ & Yanoviak \& Kaspari (2000) \\
\hline Psidium guajava $\mathrm{L}$. & Myrtaceae & Tree & Naturalized & $\begin{array}{l}\text { Camponotus textor } \\
\text { (Forel) }\end{array}$ & This paper \\
\hline Styrax camporum Pohl & Styracaceae & Tree/Shrub & Native & $\begin{array}{l}\text { Camponotus senex } \\
\text { (Smith) }\end{array}$ & Santos \& Del-Claro (2009) \\
\hline Syzygium jambos (L.) Alston & Myrtaceae & Tree & Naturalized & $\begin{array}{l}\text { Camponotus textor } \\
\text { (Forel) }\end{array}$ & $\begin{array}{l}\text { Pérez-Lachaud et al } \\
\text { (2013)/This paper }\end{array}$ \\
\hline Tapirira guianensis Aubl. & Anacardiaceae & Tree & Native & $\begin{array}{l}\text { Camponotus senex } \\
\text { (Smith) }\end{array}$ & Santos \& Del-Claro (2009) \\
\hline Virola koschnyi Warb. & Myristicaceae & Tree & - & $\begin{array}{l}\text { Camponotus textor } \\
\text { (Forel) }\end{array}$ & Longino (2006) \\
\hline Vochysia ferruginea Mart. & Vochysiaceae & Tree & Native & $\begin{array}{l}\text { Camponotus textor } \\
\text { (Forel) }\end{array}$ & Longino (2006) \\
\hline
\end{tabular}

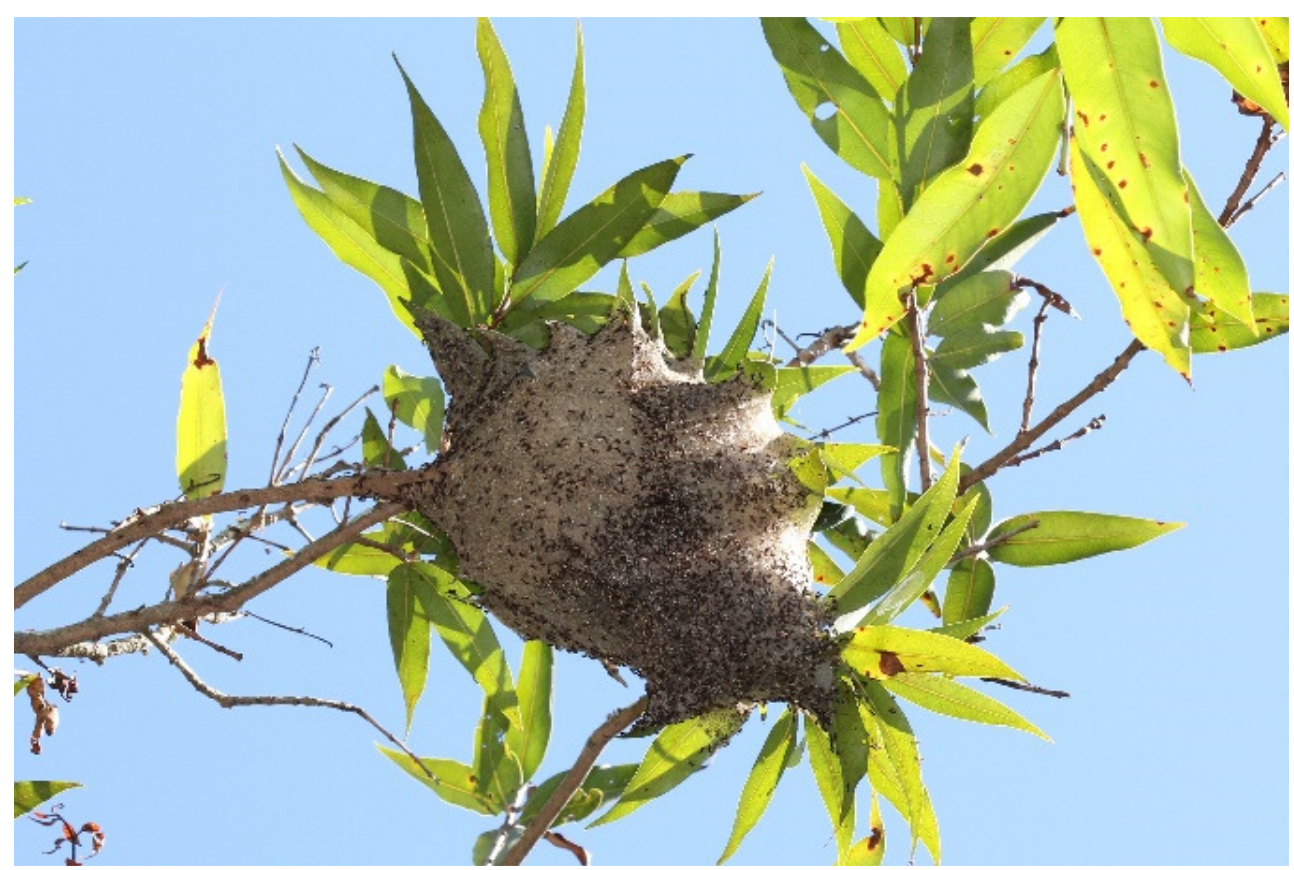

Figure 1. A Camponotus textor nest built on a Syzygium jambos (Myrtaceae) at Parque do Sabiá, Uberlândia, Minas Gerais, Brazil. 


\section{Discussion}

Several host plant species (24 species) can favor the weaver ant Camponotus textor, but this number is low when compared with the Oecophylla spp. Lim et al. (2008) examined the literature records of weaver ant host plants from 1900 to 2006. They revealed that Oecophylla smaragdina, native to Asia, was recorded on 175 plant species in 46 families and Oecophylla longinoda Latreille, 1802. Native to Africa was recorded on 66 plant species in 34 families (Lim et al., 2008). Both Oecophylla spp. shared host records on 17 economically important plant species. Such host plants could be used to augment establishment of weaver ants, facilitating their role as deterrents of phytophagous insect pests of economically important plants (Lim et al., 2008).

This study also revealed that $C$. textor $(=C$. senex) occurred on host plant species with important economic value or that have a value to human society (e.g., M. indica and Coffea. arabica). The results of the host plant survey suggested that the ant preferred some host plant species (e.g., $M$. indica) to others, but they were not conclusive. Comparing the relative abundance of ant-occupied trees for various host plant species in the same habitat could determine the selection preferences of the ant for those present case.

\section{Conclusion}

Recent studies suggest that $C$. senex $(=C$. textor) demonstrates high efficiency on removing herbivores in mango trees consequently reducing the foliar damage in those trees (Aguiar \& Santos, unpublished data). Although some studies suggest the potential of C. textor in biocontrol (e.g. Santos et al. 2005), very few studies were done with this species in this scope. On the other hand, many studies have shown high efficiency of weaver ants in biocontrol in many cultures as mango, cocoa, coffee, citrus, cashew, among others (see Van Mele, 2008 for a review).

Studies aiming to increase the locations record and the host plant species to $C$. textor are highly desirable due to its great importance in future research in the scope of biocontrol of these species. In this way, the present study represents a significant contribution to the future studies aiming biocontrol with these species of weaver ants introducing new hosts species that can be used in biocontrol systems.

\section{Acknowledgements}

The authors thanks to Programa de PósGraduação em Entomologia of Faculdade de Filosofia Ciências e Letras de Ribeirão PretoUniversidade de São Paulo (USP). This research was supported by funds from FAPEMIG APQ02543-10. KDC thanks to CNPq and CAPES. Thanks to administration Parque do Sabiá (Fundação Uberlandense do Turismo Esporte e Lazer-FUTEL; Prefeitura Municipal de Uberlândia).

\section{References}

APG III. 2009. An update of the Angiosperm Phylogeny Group classification for the orders and families of flowering plants: APG III. Bot. J. Linn. Soc., v.161, n.2, p.105-121.

BLÜTHGEN, N.; FIEDLER, K. 2002. Interactions between weaver ants Oecophylla smaragdina, homopterans, trees and lianas in an Australian rain forest canopy. J. Anim. Ecol., v.71, n.5, p.793-801.

BLÜTHGEN, N.; STORK, N. E.; FIEDLER, K. 2004. Bottom-up control and co-occurrence in complex communities: honeydew and nectar determine a rainforest ant mosaic. Oikos, v.106, n.2, p.344-358.

BRONSTEIN, J. L. 1998. The contribution of antplant protection studies to our understanding of mutualism. Biotropica, v.30, n.2, p.150-161.

DELABIE, J. H. C. 2001. Trophobiosis between Formicidae and Hemiptera (Sternorrhyncha and Auchernorryncha): an overview. Neotrop. Entomol., v.30, n.4, p.501-516.

DEL-CLARO, K.; TOREZAN-SILINGARDI, H. M. 2012. Ecologia das Interações Plantas Animais: uma abordagem ecológico-evolutiva. Technical Books.

GRACE, T. L.; LAURENCE, G. K.; SCOTT, M. S.; LOKE, T. K.; RICHARD, D. F. F.; DOUGLAS, G. P. 2008. Host plants and associated trophobionts of the weaver ants Oecophylla spp. (Hymenoptera: Formicidae). CAB Reviews: Perspectives in Agriculture, Veterinary Science, Nutrition and Natural Resources, v.3, n.35, p.1-9.

GONTHIER, D. J. 2012. Do Herbivores Eavesdrop on Ant Chemical Communication to Avoid Predation? PLoS ONE, v.7, n.1, p.e28703.

HANSSON, C.; LACHAUD, J. P.; PÉREZLACHAUD, G. 2011. Entedoninae wasps Hymenoptera, Chalcidoidea, Eulophidae) associated with ants (Hymenoptera, Formicidae) in tropical America, with new species and notes on their biology. Zookeys, v.134, p.65-82. 
HÖLLDOBLER, B.; WILSON, E. O. 1977. Weaver ants. Sci. Am., v.237, n.6, p.146-154.

HÖLLDOBLER, B.; WILSON, E. O. 1990. The ants. The Belknap Press of Harvard University Press, Cambridge.

HÖLLDOBLER, B. 1983. Territorial behavior in the green tree ant (Oecophylla smaragdina). Biotropica, v.15, p.241-250.

JOLIVET, P. 1996. Ants and plants: an example of coevolution. Backhuys Publishers, Leiden.

LIM, G. T.; KIRTON, L. G.; SALOM, S. M.; FELL, R. D.; PFEIFFER, D. G. 2008. Host plants and associated trophobionts of the weaver ants Oecophylla spp. (Hymenoptera: Formicidae). CAB Reviews Perspectives in Agriculture Veterinary Science Nutrition and Natural Resources, v.3, p.19.

MAJER, J. D.; DELABIE, J. H. C.; SMITH, M. R. B. 1994. Arboreal ant community patterns in Cocoa farms, of the arboreal ant mosaic in Ghana, Brazil, Papua New Guinea and Australia-its structure and influence on arthropod diversity. Biotropica, v.26, p.73-83.

PENG, R. K.; CHRISTIAN, K.; GIBB, K. 1995. The effect of the green ant, Oecophylla smaragdina (Hymenoptera: Formicidae), on insect pests of cashew trees in Australian. Bull. Entomol. Res., v.85, p.279-284.

PÉREZ-LACHAUD, G.; GATES, M. W.; LACHAUD, J. P. 2013. New Host Record for Camponotophilus delvarei (Hymenoptera: Eurytomidae), a Parasitoid of Microdontine Larvae (Diptera: Syrphidae), Associated with the Ant Camponotus sp. aff. textor. Psyche, v.2013.

PÉREZ-LACHAUD, G.; LACHAUD, J. P. 2014. Arboreal Ant Colonies as 'Hot-Points' of Cryptic Diversity for Myrmecophiles: The Weaver Ant Camponotus sp. aff. textor and Its Interaction Network with Its Associates. PLoS ONE, v.9, n.6, p.e100155.

PHILPOTT, S. M. 2005. Changes in arboreal ant populations following pruning of coffee shadetrees in Chiapas, Mexico. Agrofor. Syst., v.64, p.219-224.

PHILPOTT, S. M.; PERFECTO, I.; VANDERMEER, J. 2008. Behavioral Diversity of Predatory Arboreal Ants in Coffee
Agroecosystems. Environ. Entomol., v.37, p.181191.

ROSA, A. G.; ISCHIAVINI, I. 2006. Estrutura da comunidade arborea em um remanescente florestal urbano (Parque do Sabia, Uberlandia, MG). Bioscience Journal, v.22, p.151-162.

SANTOS, J. C.; KORNDÖRFER, A. P.; DELCLARO, K. 2005. Defensive behavior of the weaver ant Camponotus (Myrmobrachys) senex (Formicidae: Formicinae): drumming and mimicry. Sociobiology, v.46, p.279-288.

SANTOS, J. C.; DEL-CLARO, K. 2009. Ecology and behaviour of the weaver ant Camponotus (Myrmobrachys) senex. J. Nat. Hist., v.43, p.14231435.

SCHREMMER, F. 1979a. Das Nest der neotropischen Weberameise Camponotus Myrmobrachys) senex Smith (Hymenoptera: Formicidae). Zool. Anz., v.203, p.273-282.

SCHREMMER, F. 1979b. Die nahezu unbekannte neotropische Weberameise Camponotus (Myrmobrachys) senex (Hymenoptera: Formicidae). Entomol. Gen., v.5, n.4, p.363-378.

SPORLEDER, M.; RAPP, G. 1998. The effect of Oecophylla longinoda (Latr.) (Hym., Formicidae) on coconut palm productivity with respect to Pseudotheraptus wayi Brown (Hem., Coreidae) damage in Zanzibar. J. Appl. Ent., v.122, p.475481.

VAN MELE, P.; CUC, N. T. T. 2000. Evolution and status of Oecophylla smaragdina (Fabricius) as a pest control agent in citrus in the Mekong Delta, Vietnam. Int. J. Pest Manag., v.46, p.295-301.

VAN MELE, P. 2008. Biological control with the weaver ant Oecophylla longinoda in Africa: A review of research and development efforts to link farmers to organic markets. Outlooks on Pest Management, v.19, p.180-183.

VAN MELE, P.; VAN LENTEREN, J. C. 2002. Survey of current crop managent pratices in a mixed-ricefield landscape, Mekong Delta, Vietnam - potential of habitat manipulation for improved control of citrus leafminer and citrus red mite. Agric. Ecosyst. Environ., v.88, p.35-48.

VAN MELE, P. 2008. A historical review of research on the weaver ant Oecophylla in 
Journal of Environmental Analysis and Progress V. 01 N. 01 (2016) 111-116

biological control. Agric. Forest Entomol., v.10, p.13-22.

WAY, M. J.; KHOO, K. C. 1991. Colony dispersion and nesting habits of the ants, Dolichoderus thoracicus and Oecophylla smaragdina (Hymenoptera: Formicidae), in relation to their success as biological control agents on cocoa. Bull. Entomol. Res., v.81, p.341-350.

WAY, M. J.; KHOO, K. C. 1991. Colony dispersion and nesting habits of the ants, Dolichoderus thoracicus and Oecophylla smaradigna (Hymenoptera: Formicidae), in relation to their success as biological control agents on cocoa. Bull. Ent. Res., v.81, p.341-350.

WAY, M. J.; KHOO, K. C. 1992. Role of ants in pest management. Annu. Rev. Entomol., v.37, p.479-503.

YANOVIAK, S. P.; KASPARI, M. 2000. Community structure and the habitat templet: ants in the tropical forest canopy and litter. Oikos, v.89, p.259-266. 